\title{
Molecular detection on culture medium of Acidobacteria from Amazon soils
}

\author{
Acácio Aparecido Navarrete ${ }^{1 *}$, Cristine Chaves Barreto ${ }^{2}$, Marcela Arnaldo ${ }^{1}$ and Siu Mui Tsai ${ }^{1}$ \\ *Correspondence: acacionavarrete@gmail.com \\ ${ }^{1}$ Cell and Molecular Biology Laboratory, Center for Nuclear Energy in Agriculture CENA, University of São Paulo USP, \\ Piracicaba, SP, Brazil. \\ ${ }^{2}$ Catholic University of Brasília, Graduate Program in Genomic Sciences and Biotechnology, SGAN 915, Brasília - DF, \\ 70790-160, Brazil.
}

\begin{abstract}
Cultivation and molecular approaches were combined to recover and detect Acidobacteria from Amazon soils on culture medium. The strategy of the cultivation procedure included the following: the use of VL55 growth medium supplemented with $0.05 \%$ xylan as the carbon source and solidified with gellan gum; incubation under hypoxic conditions $\left(2 \% \mathrm{O}_{2}\right.$ [vol/vol], $2 \% \mathrm{CO}$ [ [vol/vol], and $96 \% \mathrm{~N}_{2}[\mathrm{vol} / \mathrm{vol}]$ ) for a relatively long period; inclusion of aluminium potassium sulphate in the growth medium; and soil dilution and plating. Of the 456 colonies recovered on the growth medium and subjected to PCR screening, three colonies belonging to Acidobacteria subdivision 1 and one colony belonging to Acidobacteria subdivision 3 were detected. The use of 16S rRNA gene based clone libraries comprising 437 clones confirmed that members of the phylum Acidobacteria grew primarily on plates on wich acidobacterial colonies were detected by PCR screening. The clones in the libraries consisted predominantly of Proteobacteria (orders Burkholderiales and Xanthomonadales). In summary, this work reports the recovery and molecular detection on VL55 growth medium of representatives of Acidobacteria subdivisions 1 and 3 concomitantly with to other bacterial groups inhabiting pasture and soybean cropland soils from the Amazon region.
\end{abstract}

Keywords: Soil microbiology, tropical rainforest soils, molecular PCR screening, Acidobacteria subdivisions 1 and 3

\section{Introduction}

The existence of large phylogenetic groups of bacteria that are poorly represented by cultivated strains has been revealed by culture-independent molecular surveys. Comparative phylogenetic analyses of the DNA sequences of $16 \mathrm{~S}$ rRNA genes have shown that bacterial groups, such as the Acidobacteria, are ubiquitous and among the most abundant in different environments, including soil (Barns et al., 1999; Hugenholtz et al., 1998; Janssen, 2006). In spite of their high abundance, however, there are few members of Acidobacteria that have been cultured to date. Of 142,153 high-quality $16 \mathrm{~S}$ rRNA gene sequences available from bacterial isolates (Ribosomal Database Project (RDP) II v10.4; http://rdp.msu.edu/), only 141 are classified as Acidobacteria, with cultured representatives of only 5 subdivisions $[\mathbf{1}, \mathbf{2}, \mathbf{3}, \mathbf{4}$, and $\mathbf{6}]$ of the current 26 subdivisions (Barns et al., 2007; Hugenholtz et al., 1998; Zimmermann et al., 2005).

The culture-independent approach based on the direct recovery of bacterial $16 \mathrm{~S}$ rRNA from tropical soils indicated the predominance of Acidobacteria in soils from Western Amazon (Kim et al., 2007; Jesus et al., 2009), Central Amazon (Navarrete et al., 2010), Southeastern Amazon (Navarrete et al., 2013), and the Brazilian Cerrado (Araujo et al., 2012). Among the 26 acidobacterial subdivisions classified, subdivisions [1-7, 10,11,13,16-18,22, and 25] have been detected in Amazon soils using 16S rRNA gene pyrosequencing (Navarrete et al., 2013 and Cannavan, 2012). Acidobacteria subdivisions
$[1,2$ and 3$]$ were reported to be dominant in soils from primary forests, soybean cropland fields, and pasture. In contrast, in the anthrosols associated with pre-Colombian settlements in the Amazonian region - Amazonian Dark Earth - Acidobacteria subdivisions [4 and 6] were dominant members within acidobacterial communities.

Despite the high abundance of acidobacterial 16S rRNA gene sequences recovered from the Amazon soils, there are no cultured representatives of Acidobacteria from this tropical ecosystem. Although many laboratories are attempting to obtain pure cultures of Acidobacteria from different environments worldwide, the taxonomically described diversity within this group remains very limited. More than half of the currently characterised Acidobacteria belong to subdivision [1], and only 18/141 high-quality $16 \mathrm{~S}$ rRNA gene sequences from bacterial isolates are classified as subdivision [3] (Ribosomal Database Project (RDP) II v10.4; http://rdp.msu.edu/). Members of Acidobacteria subdivision [1] have been isolated from diverse soils (Janssen et al., 2002; Sait et al., 2002; Joseph et al., 2003; Eichorst et al., 2007; Koch et al., 2008; Stott et al., 2008), acidic mineral environments (Kishimoto et al., 1991), the termite hindgut (Eichorst et al., 2007), Sphagnum-dominated wetlands (Pankratov et al., 2008, 2012; Pankratov and Dedysh, 2010), decaying wood (Folman et al., 2008; Valášková et al., 2009) and methanotrophic enrichment culture (Koch et al., 2008; Dedysh et al., 2012). Acidobacteria subdivision [3] representatives have been isolated from soil (Sait et al., 2002; Joseph et al., 2003; 


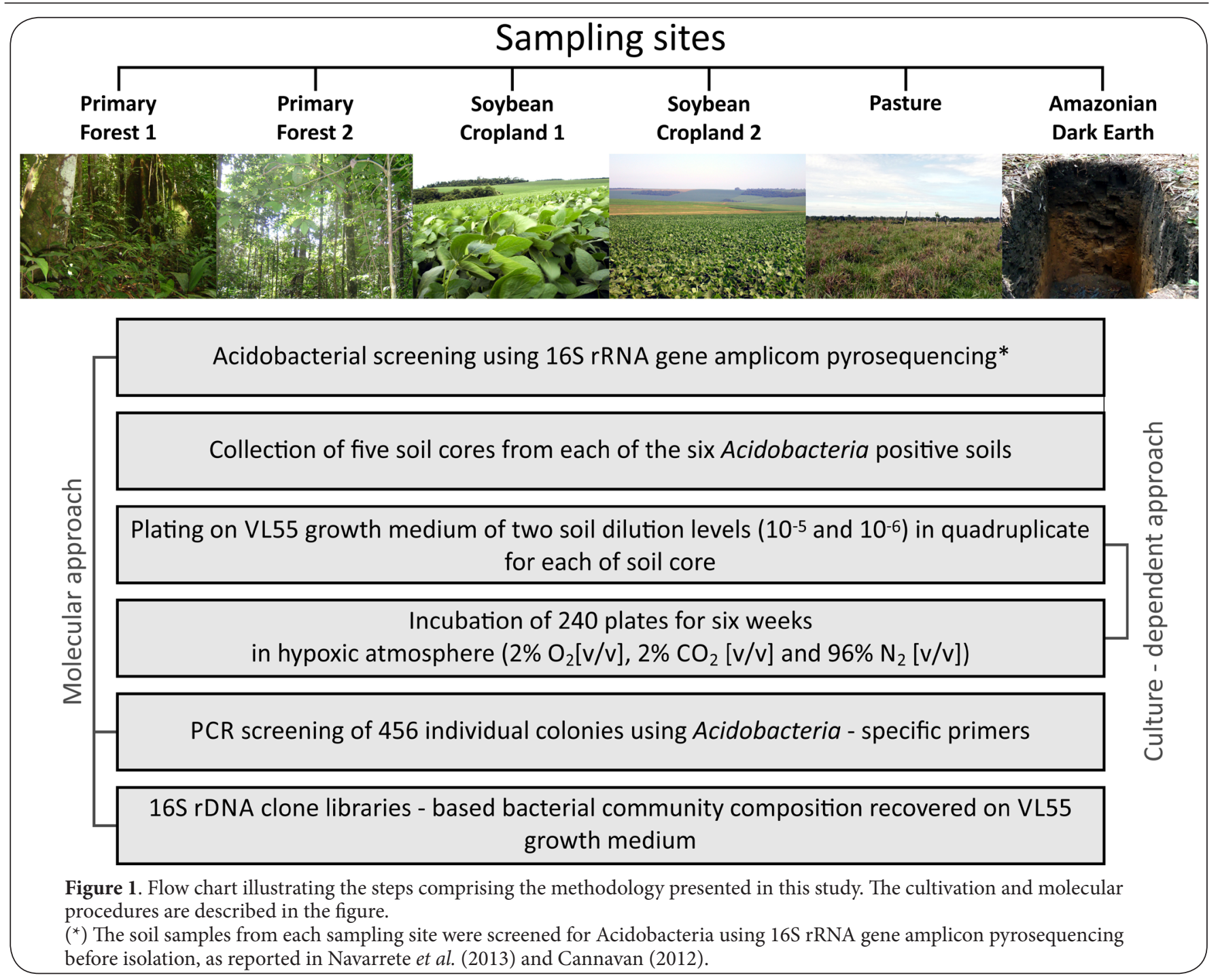

Davis et al., 2011; Eichorst et al., 2011) and acidic Sphagnum peat bog (Dedysh et al., 2006; Kulichevskaya et al., 2010).

In this work, we took advantage of the treatments tested in Stevenson et al., (2004) and Davis et al., (2005), combining cultivation and molecular approaches to recover and detect Acidobacteria from Amazon soils on laboratory media. For this purpose, a high carbon concentration was provided in the culture medium, and the samples were maintained under hypoxic conditions $\left(2 \% \mathrm{O}_{2}, 2 \% \mathrm{CO}_{2}\right.$, and $\left.96 \% \mathrm{~N}_{2}\right)$ with a long incubation time. We performed a laboratory cultivation experiment using Acidobacteria-positive soils from primary forest, soybean cropland fields, pasture and Amazonian Dark Earth sites located in the Brazilian Amazon region as the inoculum and previously screened for Acidobacteria using $16 \mathrm{~S}$ rRNA gene amplicon pyrosequencing (Navarrete et al., 2013 and Cannavan, 2012.

\section{Materials and methods}

Cultivation and molecular approaches were combined to recover and detect Acidobacteria from Amazon soils on culture medium according to the procedure shown in the methodological flow chart illustrated in (Figure 1). A detailed description of the methodology is shown in the subsequent sections of this paper.

\section{Soil collection and manipulation}

The soil samples were collected in November 2011 from six different sampling sites located at three different municipalities in the Brazilian Amazon region: (1) Porto dos Gaúchos municipality $\left(-15^{\circ} 13^{\prime} 39^{\prime \prime} \mathrm{S}\right.$ and $\left.-54^{\circ} 04^{\prime} 31^{\prime \prime} \mathrm{W}\right)$, state of Mato Grosso, in primary forest (PF-1) and soybean cropland fields (SC-1); (2) Ipiranga do Norte municipality $\left(-13^{\circ} 21^{\prime} 57^{\prime \prime} \mathrm{S}\right.$ and $-54^{\circ} 54^{\prime} 24^{\prime \prime} \mathrm{W}$ ), state of Mato Grosso, in primary forest (PF2 ), soybean cropland fields (SC-2), and pasture (Brachiaria brizantha) (PA); and (3) Iranduba municipality $\left(03^{\circ} 18^{\prime} 25^{\prime \prime} S\right.$ and $60^{\circ} 32^{\prime} 05^{\prime \prime} \mathrm{W}$ ), state of Amazonas, in an anthropogenic soil site characterised as Amazonian Dark Earth (ADE). Oxisol is the predominant soil order in the field sites located in Mato 


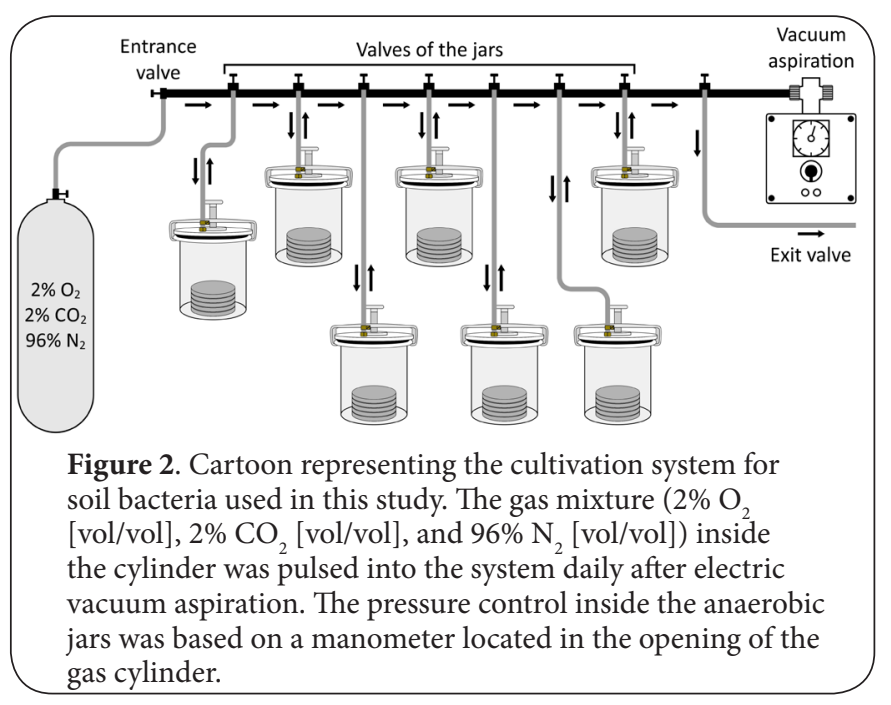

Grosso (SEPLAN, 2001); the soil at the ADE site is classified as Hortic Anthrosol according to the World Reference Base for Soil Resources (FAO, 1998).

Five soil cores ( $5 \mathrm{~cm}$ in diameter, 0 - to $20-\mathrm{cm}$ topsoil layer) were collected from each sampling site using a cylindrical soil corer aseptically and transported to the laboratory in a sealed polyethylene bag at ambient temperature and stored overnight at $4{ }^{\circ} \mathrm{C}$. The soil samples were collected from five sampling points at each site, with one central sampling point and other four sampling points (at least $50 \mathrm{~m}$ away from the central point) directed toward the north, south, east, and west of the central point. An accurately weighed aliquot of soil (6 $\mathrm{g}$ fresh weight) from each of the five soil samples per sampling site was suspended in $100 \mathrm{~mL}$ sterile salt solution (3.9 g 2-[N-morpholino] ethanesulphonic acid, $0.4 \mathrm{mM} \mathrm{MgSO}_{4^{\prime}} 0.6$ $\mathrm{mM} \mathrm{CaCl}{ }_{2}$ and $0.4 \mathrm{mM}\left(\mathrm{NH}_{4}\right)_{2} \mathrm{HPO}_{4}$ per litre) and mixed using a Teflon-coated magnetic bar for $15 \mathrm{~min}$ at approximately 200 r.p.m. The resulting suspensions were serially diluted in 10 fold steps by the addition of $1 \mathrm{~mL}$ of the previous dilution to $9 \mathrm{~mL}$ sterile salt solution, stirring for $5 \mathrm{~min}$ between dilutions. Volumes of $100 \mathrm{~mL}$ from the $10^{-5}$ and $10^{-6}$ dilutions of the soil were spread onto plates of VL55 medium (see below) using a sterile glass spreader.

\section{Cultivation experiment}

Four replicate plates per soil dilution and sampling site were incubated under hypoxic conditions $\left(2 \% \mathrm{O}_{2}[\mathrm{vol} / \mathrm{vol}], \mathrm{CO}_{2}\right.$ (2\% [vol/vol], and $96 \% \mathrm{~N}_{2}[\mathrm{vol} / \mathrm{vol}]$ ) at room temperature in a cultivation system, as illustrated in Figure 2. All the cultures were maintained under low light conditions at room temperature (24 to $26^{\circ} \mathrm{C}$ ) for six weeks, and the number of colonies was then counted per plate the colonies used to determine the colony counts were visible using a colony counter fitted with a $1.5 x$ magnifying lens. The VL55 base contained $3.9 \mathrm{~g}$ 2-[N-morpholino] ethanesulphonic acid, $0.4 \mathrm{mM} \mathrm{MgSO}_{4^{\prime}} 0.6$ $\mathrm{mM} \mathrm{CaCl}{ }_{2}, 0.4 \mathrm{mM}\left(\mathrm{NH}_{4}\right)_{2} \mathrm{HPO}_{4^{\prime}} 2 \mathrm{~mL}$ of selenite/tungstate solution (Tschech and Pfennig, 1984), and $0.8 \%$ gellan gum per litre. Gellan gum provides a more transparent medium than agar, facilitating the visualisation of the colonies. The $\mathrm{pH}$ was adjusted to 5.5 with a mixture of $200 \mathrm{mM} \mathrm{NaOH}$ plus $100 \mathrm{mM} \mathrm{KOH}$. This medium base was autoclaved at $121^{\circ} \mathrm{C}$ for $20 \mathrm{~min}$ and cooled to $56^{\circ} \mathrm{C}$. A $10 \mathrm{~mL}$ aliquot of $5 \%(\mathrm{w} / \mathrm{v})$ xylan from beechwood (Fluka), $2 \mathrm{~mL}$ vitamin solution (see below), and $2 \mathrm{~mL}$ of a trace element solution SL-10 (Widdel et al., 1983) with inclusion of aluminium potassium sulphate $(0.01 \mathrm{~g} / \mathrm{L})$ were added per litre of medium base. The selenite/ tungstate, vitamin, and trace element solutions were added after membrane filtration. The vitamin solution contained (per litre of $\mathrm{H}_{2} \mathrm{O}$ ) $2 \mathrm{mg}$ (+)-biotin, $2 \mathrm{mg}$ folic acid, $10 \mathrm{mg}$ pyridoxamine hydrochloride, $5 \mathrm{mg}$ thiamine chloride, $5 \mathrm{mg}$ riboflavin, $5 \mathrm{mg}$ nicotinic acid, $5 \mathrm{mg}$ hemicalcium D-(+)pantothenate, $0.1 \mathrm{mg}$ cyanocobalamin, $5 \mathrm{mg}$ 4-aminobenzoate and $5 \mathrm{mg}$ DL-6,8-thioctic acid. Cycloheximide $1 \mu \mathrm{g} / \mathrm{mL}$ was added as antifungal agent. This medium was used for both enumeration and subcultivation.

\section{PCR screening for Acidobacteria on culture plates and subcultivation}

After six weeks of incubation, screening for acidobacterial colonies was performed with Acidobacteria-specific primers and Acidobacterium capsulatum (DSM 11244) as a positive control in the $P C R$ reactions. A total of 456 individual colonies were subjected to screening for Acidobacteria by PCR. For picking individual colonies, the plates were viewed with illumination from a cool white light. Unreplicated PCR reaction was performed for each individual colony after cells lysis in $50 \mu \mathrm{L} 1 \times$ Tris-EDTA (TE) buffer $(10 \mathrm{mM}$ Tris- $\mathrm{HCl}$ and 1 mM EDTA, pH 8.0) using a thermal cycler (Applied Biosystems, CA, USA) for 10 min at $96^{\circ} \mathrm{C}$. Each $25-\mu \mathrm{L}$ PCR reaction contained approximately $50 \mathrm{ng}$ template DNA, $1 \mathrm{x}$ reaction buffer (Invitrogen, CA, USA), $1.5 \mathrm{mM} \mathrm{MgCl}, 0.25 \mathrm{mM}$ each deoxynucleoside triphosphate, $0.2 \mu \mathrm{M}$ each forward Acid31F (5'-GATCCTGGCTCAGAATC-3') (Barns et al., 1999) and reverse 1492R (5'-TACGGYTACCTTGTTACGACTT-3') (Lane, 1991) primer, and 1.0 U Taq DNA polymerase (Invitrogen, CA, USA). The PCR mixtures were incubated in a GeneAmp PCR System 9700 thermal cycler (Applied Biosystems, CA, USA) for the following amplification cycles: $3 \mathrm{~min}$ at $95^{\circ} \mathrm{C} ; 30$ cycles of $1.5 \mathrm{~min}$ at $95^{\circ} \mathrm{C}, 1 \mathrm{~min}$ at $52^{\circ} \mathrm{C}$, and $1.5 \mathrm{~min}$ at $72^{\circ} \mathrm{C}$; followed by $10 \mathrm{~min}$ at $72^{\circ} \mathrm{C}$.

The PCR products were analysed by electrophoresis of $5 \mu \mathrm{L}$ of the reaction mixture on $1 \%$ agarose gels at 100 $V$ in $0.5 x$ Tris-borate-EDTA, visualised by UV illumination after staining with GelRed (Biotium Inc., CA, USA), and photographed. Based on the A. capsulatum-positive product, four individual colonies of Acidobacteria were detected, and the cell lysis material obtained from these colonies and $A$. capsulatum-positive colony was used as the template in PCR reactions separately performed with the universal bacterial primers 27F (5'-AGAGTTTGATCCTGGCTCAG-3') and 1492R 
Navarrete et al. Microbiology Discovery 2013,

(5'-AAGGAGGTGATCCAGCC-3') (Weisburg et al., 1991). Each $25-\mu \mathrm{L}$ reaction mixture contained approximately $50 \mathrm{ng}$ template DNA, 1x PCR buffer (Invitrogen, CA, USA), $1.5 \mathrm{mM}$ $\mathrm{MgCl}_{2}, 0.1 \mathrm{mM}$ each deoxynucleoside triphosphate, $0.2 \mu \mathrm{M}$ each forward (F) and reverse (R) primer, and $1.25 \cup$ Taq DNA polymerase (Invitrogen, CA, USA). The PCR mixtures were incubated in a GeneAmp PCR System 9700 thermal cycler (Applied Biosystems, CA, USA) for the following amplification cycles: $96{ }^{\circ} \mathrm{C}$ for $4 \mathrm{~min} ; 30$ cycles of $94{ }^{\circ} \mathrm{C}$ for $1 \mathrm{~min}, 55^{\circ} \mathrm{C}$ for $30 \mathrm{~s}$, and $72{ }^{\circ} \mathrm{C}$ for $2 \mathrm{~min}$; and $72{ }^{\circ} \mathrm{C}$ for $10 \mathrm{~min}$. The PCR products were purified using the Qiagen $P C R$ purification kit (Qiagen, CA, USA) after analysis by gel electrophoresis. The PCR products were then ligated into the $P G E M-T$ easy vector (Promega, WI, USA) and transformed into competent E. coli $\mathrm{DH} 5 \mathrm{a}$ cells. Four clones per detected acidobacterial colony were randomly selected and sequenced. Partial sequencing for the 16S rRNA gene was performed for each clone using the primers 27F, 1492R, 518F (5'-CCAGCAGCCGCGGTAATACG-3'), and $800 R$ ( $5^{\prime}$-TACCAGGGTATCTAATCC-3'), the BigDye Terminator v3.1 cycle sequencing kit (Applied Biosystems, CA, USA), and an ABI 3730xI DNA Analyzer capillary sequencer (Applied Biosystems, CA, USA) (Macrogen Inc. Company, South Korea). Taxonomy was assigned to the sequences using Ribosomal Database Project (RDP) 2 classifier (release 10.4) (http://rdp. cme.msu.edu/). Partial sequences (1000 - 1488 bp) for the $16 \mathrm{~S}$ rRNA gene of the detected acidobacterial colonies - PA (1.5), PA (2.1), PA (2.6), and SC-2 (3.2) - were deposited in the GenBank Database (http://www.ncbi.nlm.nih.gov/genbank/) under accession numbers KC121330, KC121331, KC121328, and KC121329, respectively.

The four detected acidobacterial colonies (three colonies from pasture soil - PA (1.5), PA (2.1), and PA (2.6) - and one colony from soybean cropland soil - SC-2 (3.2) were subcultured according to the description in section 2.2.

\section{DNA Isolation, amplification, and construction of $16 \mathrm{~S}$} rRNA gene clone libraries

Colonies were partially kept on the surface of the plates after picking colonies procedure for PCR screening as described above. For construction of the 16S rRNA gene clone libraries, the surface of these plates was flooded with $2 \mathrm{~mL}$ of bead solution from the Power Soil DNA Isolation Kit (MO BIO Laboratories Inc., CA, USA), and a sterile spreader was used to suspend as much of the colony material as possible. The colony material was pooled from isolation plates for each of the six soil types. The bead solution with suspended cells was transferred to a dry bead tube from the DNA kit, $50 \mu \mathrm{L}$ of lysozyme solution ( $50 \mathrm{mg} / \mathrm{mL}$; Sigma-Aldrich) was added, and the tube was incubated for $30 \mathrm{~min}$ in a $37^{\circ} \mathrm{C}$ water bath. DNA isolation was then performed according to the manufacturer's protocol. The 16S rRNA gene fragments were amplified using the PCR universal bacterial primers $27 \mathrm{~F}$ and $1492 \mathrm{R}$ (Weisburg et al., 1991) as described. The PCR products were purified using the Qiagen PCR purification kit (Qiagen, CA, USA) after analysis by gel electrophoresis. The PCR products were ligated into the PGEM-T easy vector (Promega, WI, USA) and transformed into competent $E$. coli $\mathrm{DH} 5$ a cells. Six different clone libraries were constructed, one for each soil type. A total of 437 clones were randomly selected and sequenced using the vector primer M13F (5'-GCCAGGGTTTTCCCAGTCACG-3') (Huey and Hall, 1989), the BigDye Terminator v3.1 cycle sequencing kit (Applied Biosystems, CA, USA), and an ABI 3730xI DNA Analyzer capillary sequencer (Applied Biosystems, CA, USA). The libraries were constructed for the DNA samples from the isolation plates inoculated with PF soils (PF-1 GenBank accession nos. JX574664 - JX574723 and PF-2 GenBank accession nos. JX574724 - JX574770), SC soils (SC-1 GenBank accession nos. JX574771 - JX574828 and SC-2 GenBank accession nos. JX574829 - JX574911), PA soil (GenBank accession nos. JX574912 - JX574988), and ADE soil (GenBank accession nos. JX574989 - JX575075).

\section{Clustering clones into operational taxonomic units and phylogenetic analysis}

The 16S rRNA gene sequences were edited using Phred/Phrap (Ewing et al., 1998). Taxonomy was assigned to the sequences using Ribosomal Database Project (RDP) 2 classifier (release 10.4) (http://rdp.cme.msu.edu/). The sequences were grouped into operational taxonomic units (OTUs) using MOTHUR software (Schloss et al., 2009). An OTU was defined as a group of sequences exhibiting $\geq 97 \%$ similarity to each other using the average neighbour algorithm. A representative sequence for each OTU was determined using MOTHUR software as the sequence that has the minimum distance from all other sequences within the same OTU. In addition, representative sequences for each OTU were assigned to a phylogenetic tree containing mostly related nucleotide sequences available from databases (GenBank and Ribosomal Database Project). The sequences were aligned using ClustalX2 (Larkin et al., 2007) and further clustered using neighbour-joining analysis with Kimura-2 parameters from a study conducted using MEGA version 4.0 (Tamura et al., 2007), determining the preferred phylogenetic tree, as supported by bootstrap values, based on an analysis of 1,000 subsamples.

\section{Results and Discussion}

The recalcitrance of acidobacterial taxa members to growth on culture media has been extensively reported during the past decade. However, new cultivation strategies have been considered in combination with classical microbiology methods to improve the culturability of Acidobacteria in the laboratory. Culturing techniques that have contributed to the successful isolation of Acidobacteria include the following: media with a low pH (Sait et al., 2006); increased headspace $\mathrm{CO}_{2}$ concentrations (Stevenson et al., 2004); substrate amendments (Pankratov et al., 2008); random selection of a wide variety of growth substrates (Joseph et al., 2003); the use of a diffusion chamber (Bollmann et al., 2007); and the extension of the 


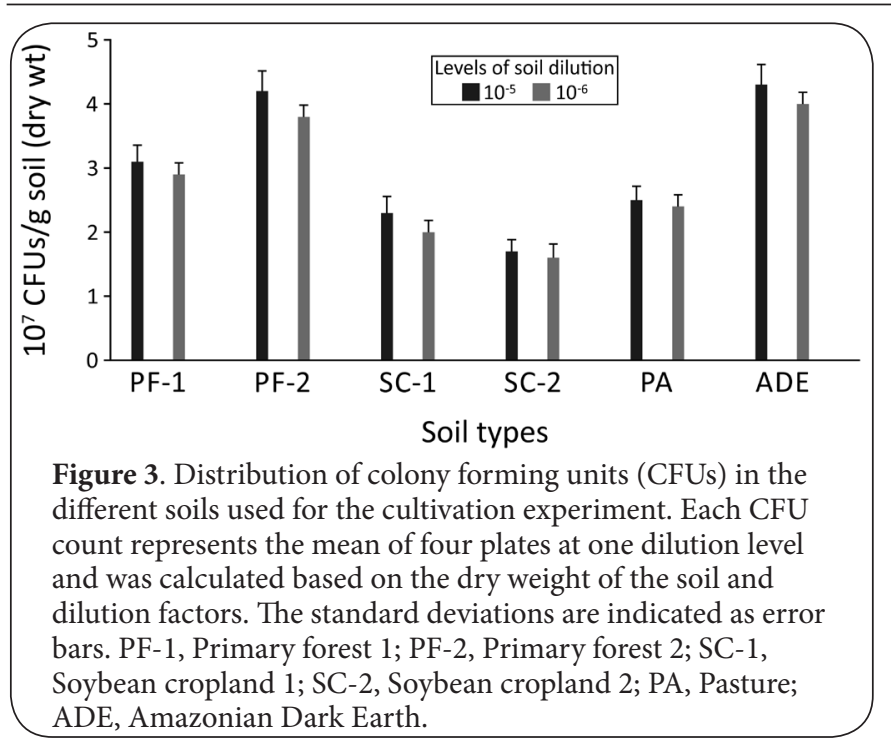

incubation time (Davis et al., 2005). Nevertheless, Acidobacteria are a bacterial group that is poorly represented in culture collections, without isolated members from Amazon soils. In the present work, we provide initial insight using a culturedependent approach for the recovery and molecular detection on culture medium of acidobacterial members that inhabit different soils from the Brazilian Amazon characterised as intact rainforest, deforested soils recently converted into cultivation and pasture, and Amazonian Dark Earth.

\section{Colony counts of soil bacteria}

In general, the plates inoculated with a $10^{-6}$ dilution of soil did not produce a significant decrease in the colony number per plate in comparison to the plates inoculated with 10 times more soil (Figure 3 ). The colony-forming units (CFU) counts ranged from a maximum of $4.3 \times 10^{7} \mathrm{~g}^{-1}$ of dry soil from the ADE site to a minimum of $1.6 \times 10^{7} \mathrm{~g}^{-1}$ of dry soybean cropland soil (SC-2 field) (Figure 3). The isolation plates inoculated with soil from the ADE site presented the highest number of bacterial colonies, followed by the plates inoculated with soils from primary forest (PF-1 and PF-2), pasture, and soybean cropland fields (SC-1 and SC-2) (Figure 3). From a temporal perspective, visible colonies firstly appeared on the surface of the plates inoculated with the soil from the ADE site (after one week of incubation), secondly on the plates inoculated with the primary forest soils (after one and a half weeks of incubation), and then on the plates inoculated with the soil from pasture and cropland fields (after two weeks of incubation). Three plates were unusable due to fungal contamination, a problem that may be related to the high richness of fungal populations in Amazon primary forest soils and in ADE sites (Navarrete et al., 2010; Ruivo et al., 2009).

\section{Molecular detection and identification of colonies belonging to the phylum Acidobacteria}

A total of 456 colonies from the plates containing $10^{5}$ and $10^{6}$ soil dilutions as the inoculum were picked and subjected to PCR screening with primers targeting a region of the $16 \mathrm{~S}$ rRNA-encoding gene specific to Acidobacteria. Only four acidobacterial colonies were detected by PCR from the total number of screened colonies. Three acidobacterial colonies were positively detected from the plates inoculated with PA soil (colonies PA(1.5), PA(2.1), and PA(2.6)), and one acidobacterial colony was detected from a plate inoculated with SC-2 soil (colony SG-2(3.2)). Although the plates for the initial isolation experiment were incubated for six weeks, subcultures of the acidobacterial colonies $\mathrm{PA}(1.5)$ and PA(2.1) were able to decrease the $\mathrm{pH}$ of the medium to 3.1, and hydrolysing the gellan gum within three weeks and, thus, rendering the plates unusable. Therefore, these two acidobacterial colonies could not to be isolated. The PA(1.5) colony was identified as Acidobacteria subdivision [1] (100\% identity with $16 \mathrm{~S}$ rRNA gene sequences) and the PA(2.1) colony as belonging to Acidobacteria subdivision [3] (100\% identity with $16 \mathrm{~S}$ rRNA gene sequences) (Figure 4). Based on the partial sequencing of the 16S rRNA gene (1488 bp), the acidobacterial colonies PA(2.6) and SC-2(3.2) were identified as Acidobacteria subdivision [1] (100\% identity with $16 \mathrm{~S}$ rRNA gene sequences) (Figure 4), and both were isolated and preserved by lyophilisation and mineral oil. All the four acidobacterial colonies did not grow when inoculated in liquid VL55 medium; however, PA(2.6) and SC-2(3.2) were able to grow on solid medium under atmosphere-unamended air. The subdivision [1] isolates (PA (2.6)) formed smooth and semi-transparent colonies, generally with an irregular margin at a later stage of development (> 2 months of incubation) (Figure 5).

Assessment based on the 16S rRNA gene clone libraries The ability to obtain visible colonies is a factor that may limit the apparent culturability of some microorganisms. All colonies on a growth medium do not develop at the same rate, even in pure cultures (Ishikuri and Hattori, 1985; Mochizuki and Hattori, 1986), and after extraction from the soil, some cells develop into microcolonies of just a few cells (Winding et al., 1994). Furthermore, it is not clear whether micro- or minicolonies would form visible colonies if incubated for a sufficient amount of time, or whether they have a selflimiting growth phenotype (Davis et al., 2011). However, to avoid the situation in which acidobacterial colonies would not be detected by picking isolated colonies, we used $16 \mathrm{~S}$ rRNA gene clone libraries to identify growth of Acidobacteria on the growth medium.

Of the bacterial 16S rRNA genes present on the growth medium after six weeks of incubation, 437 sequences were recovered from samples of the Amazon soils from the PF, SC, $\mathrm{PA}$, and $\mathrm{ADE}$ sites. The taxonomy assignment showed that acidobacterial clones ( $\geq 97 \%$ identity with 16 S rRNA gene sequences) were recovered only from plates inoculated with the SC and PA soils (Table 1, Figure 4). Sequences belonging 


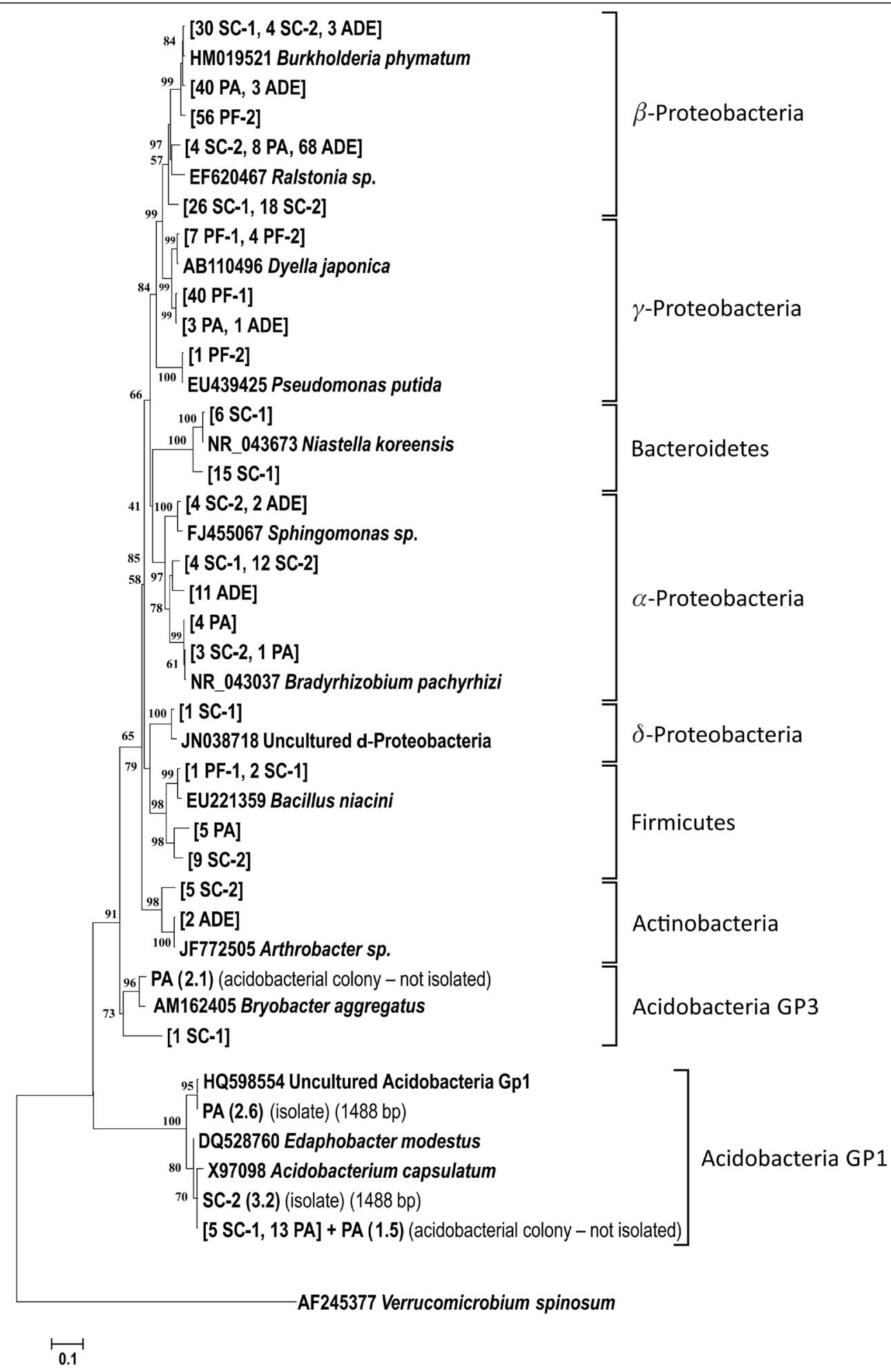

Figure 4. Phylogenetic relationships based on the partial 16S rRNA gene sequences of detected acidobacterial colonies on growth medium and representative clones from libraries constructed to assess the total bacterial community on growth medium inoculated with Amazon soils from different origins (PF, primary forest areas; SC, soybean cropland fields; PA, pasture; and ADE, Amazonian Dark Earth sites) with their best matches in the databases searched (GenBank and Ribosomal Database Project). A bootstrap analysis was performed with 1,000 repetitions, and the values indicate the percentage of clustering matches. The scale bar at the bottom of the figure displays the number of differences in the base composition among the sequences. The values and abbreviations in brackets indicate the number of clones in each OTU ( $3 \%$ cutoff point of dissimilarity) and their origins, respectively. The soil samples (PF and SC) were collected from sites located at Porto dos Gaúchos municipality (1) and Ipiranga do Norte municipality (2). 
Navarrete et al. Microbiology Discovery 2013,

http://www.hoajonline.com/journals/pdf/2052-6180-1-1.pdf

doi: $10.7243 / 2052-6180-1-1$

Table 1. Taxa and numbers of clones derived from isolation plates inoculated with soil collected from primary forest areas, soybean cropland fields, pasture, and Amazonian Dark Earth sites.

\begin{tabular}{|c|c|c|c|c|c|c|c|c|}
\hline \multirow{2}{*}{ Phylum } & \multirow{2}{*}{ Class } & \multirow{2}{*}{ Order } & \multicolumn{6}{|c|}{ Clone libraries } \\
\hline & & & PF-1 & PF-2 & SC-1 ${ }^{*}$ & SC-2* & $\mathbf{P A}^{*}$ & ADE \\
\hline \multirow[t]{2}{*}{ Acidobacteria } & Subdivision 1 & & 0 & 0 & 0 & 6 & 19 & 0 \\
\hline & Subdivision 3 & & 0 & 0 & 1 & 0 & 0 & 0 \\
\hline Actinobacteria & Actinobacteria & Actinomycetales & 0 & 0 & 0 & 5 & 0 & 2 \\
\hline Bacteroidetes & Sphingobacteria & Sphingobacteriales & 0 & 0 & 21 & 0 & 0 & 0 \\
\hline Firmicutes & Bacilli & Bacillales & 1 & 0 & 2 & 9 & 5 & 0 \\
\hline \multirow[t]{11}{*}{ Proteobacteria } & $\alpha$-Proteobacteria & Rhizobiales & 0 & 0 & 4 & 7 & 4 & 10 \\
\hline & & Sphingomonadales & 0 & 0 & 0 & 4 & 0 & 1 \\
\hline & & unclassified & 0 & 0 & 0 & 1 & 0 & 0 \\
\hline & $\beta$-Proteobacteria & Burkholderiales & 0 & 56 & 56 & 28 & 48 & 74 \\
\hline & & Rhodocyclales & 0 & 0 & 2 & 0 & 0 & 0 \\
\hline & & unclassified & 0 & 1 & 0 & 0 & 0 & 0 \\
\hline & $\delta$-Proteobacteria & Myxococcales & 0 & 0 & 1 & 0 & 0 & 0 \\
\hline & $\gamma$-Proteobacteria & Xanthomonadales & 47 & 3 & 0 & 0 & 3 & 0 \\
\hline & & Pseudomonadales & 0 & 2 & 0 & 0 & 0 & 0 \\
\hline & & Enterobacteriales & 0 & 0 & 0 & 0 & 0 & 1 \\
\hline & unclassified & & 0 & 0 & 2 & 2 & 1 & 1 \\
\hline unclassified & & & 2 & 0 & 1 & 1 & 1 & 2 \\
\hline
\end{tabular}

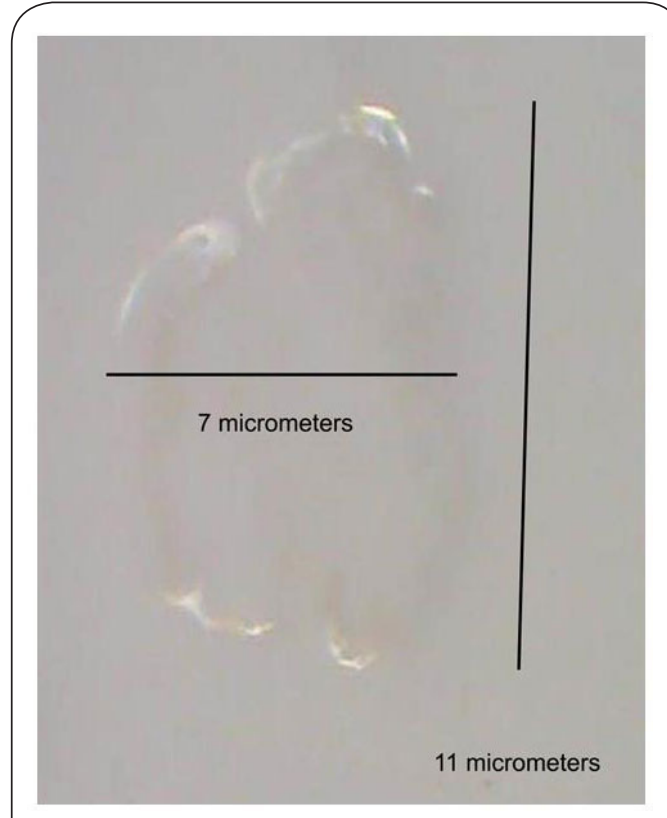

Figure 5. Example of an Acidobacteria colony recovered from pasture soil after 2 months of incubation under a gas mixture $(2 \% \mathrm{O} 2[\mathrm{vol} /$ $\mathrm{vol}$ ], $2 \% \mathrm{CO} 2[\mathrm{vol} / \mathrm{vol}]$, and $96 \% \mathrm{~N} 2[\mathrm{vol} / \mathrm{vol}])$. The picture was taken from the upper portion of the plate with a $35 \mathrm{x}$ magnification using a Luxeo 4D Zoom Stereo Microscope with an integrated camera (Labomed).

Acidobacteria subdivision [1] accounted for $10 \%$ and $23 \%$ of the total number of clones from plates inoculated with SC-2 and
PA soils, respectively. One sequence belonging Acidobacteria subdivision [3] was recovered from a plate inoculated with the SC-1 soil (Table 1, Figure 4), a result that expands that obtained with PCR screening using specific primers showing the detection of an Acidobacteria subdivision 3 representative only from the plate inoculated with the PA soil.

Although a comparative phylogenetic analysis of DNA sequences of the 16S rRNA genes revealed that subdivisions [1 and 3] are dominant in the primary forest and cropland field soils evaluated in this study (Navarrete et al., 2013), representatives of these group were recovered only from the isolation plates inoculated with the soybean cropland and pasture soils (Table 1, Figure 4). Eichorst et al., (2011) also detected members of Acidobacteria subdivisions [1 and 3] in agricultural and managed grassland soils in Michigan using molecular and cultivation-based approaches. These authors suggested that members of these two acidobacterial subdivisions have the potential to play an active role in the degradation of plant polymers in bulk soil and to utilise sugars from plant root exudates at various concentrations in the rhizosphere.

Several growth conditions have been considered in cultivation experiments to allow a better representation of acidobacterial diversity into laboratory culture. Sait et al., (2006) identified moderately acidic $\mathrm{pH}$ values as an important factor for their success in isolating many members of subdivision [1]. This condition fits with the abundance of members of this group in different soils in which they form relatively larger parts of the total community as the soil $\mathrm{pH}$ decreases (Sait et al., 2006). Pure cultures also display growth 
Navarrete et al. Microbiology Discovery 2013,

optima at moderately acidic pH values of 4.5 to 6 (Eichorst et al., 2007). Stevenson et al., (2004) found that increased $\mathrm{CO}_{2}$ partial pressures, mimicking those found in soils (Russell, 1950), increased the culturability of Acidobacteria subdivision [1], but Sait et al., (2006) and Eichorst et al., (2007) later showed that this was an effect on the $\mathrm{pH}$ of the medium. Elevated $\mathrm{CO}_{2}$ partial pressure could be particularly significant for any potentially autotrophic group, and different subsets of the soil community may have been cultured using this condition.

Library clones from the plates inoculated with the PF-1 soil consisted predominantly of Proteobacteria (order Xanthomonadales), whereas representatives of phylum Proteobacteria (order Burkholderiales) were more frequentin the PF-2 library. Clones from plates inoculated with the SC-1 and SC-2 soils were commonly related to the phyla Proteobacteria (order Burkholderiales and Rhizobiales) and Firmicutes (order Bacillales); however, sequences belonging to Bacteroidetes (order Sphingobacteriales) were recovered only from clones in the SC-1 library. Actinobacteria (order Actinomycetales) and Acidobacteria subdivision [1] were among the clones in the SC-2 library but not in the SC-1 library. The clones derived from the isolation plates inoculated with the PA soils were mostly affiliated with Proteobacteria (order Burkholderiales), followed by Acidobacteria subdivision [1]. For the isolation plates inoculated with the ADE soil, the clones were majority related to phylum Proteobacteria (orders Burkholderiales and Rhizobiales) (Table 1,Figure 4). Additionally, taxonomically unclassified bacteria were found in all the libraries, except that for PF-2.

Considering the differential occurrence of Acidobacteria on isolation plates in contrast to the growth of other bacterial groups (Table 1), it is interesting to note that, as based on the cultivation strategy employed in this study, acidobacterial colonies were detected on those plates a lower number of colonies and an increased time for visible growth (Table 1, Figure 3). These slow-growing microorganisms may have been inhibited by products from more rapidly growing colonies (Janssen, 2008; Vartoukian et al., 2010), which may be a reason why most used cultivation methods failed to culture the full extent of the phylogenetic diversity of bacteria present in environmental samples (Hugenholtz et al., 1998). This situation has been particularly apparent in attempts to culture soil bacteria, whereby both the number (Conn, 1918) and diversity (Janssen, 2006) are greatly underestimated by the most traditional cultivation-based techniques.

\section{Conclusion}

In summary, this work reports the recovery and the molecular detection on VL55 growth medium of representatives of Acidobacteria subdivisions [ 1 and 3 ] from Amazon soils under soybean cropland and pasture. The results serve as the first indication of the potential of combining cultivation and molecular approaches to grow and to detect Acidobacteria from Amazon soils on culture medium.

\section{Competing interests}

The authors declare that they have no competing interests.

\section{Authors' contributions}

AAN made substantial contributions to the conception and design of the study and acquisition, analysis, and interpretation of the data. CCB participated in the design of the study and helped to define the strategy for the cultivation procedure. MA participated in the cultivation experiment. SMT participated in the design and coordination of the study and helped to draft the manuscript. All authors read and approved the final manuscript.

\section{Acknowledgement and fundings}

This study was supported by a grant from Conselho Nacional de Desenvolvimento Científico (152084/2011-8) and Fundação de Amparo à Pesquisa do Estado de São Paulo (2008/58114-3 and 2011/50914-3). We thank J.E. Gomes, C.A. Yoshiura, L.S. Santos, and F.S. Cannavan for their technical support. E. E. Kuramae and J. A. van Veen (NIOO-KNAW, The Netherlands) are acknowledged for their valuable suggestions regarding the present work.

\section{Publication history}

Received: 10-Jan-2013 Revised: 18-Feb-2013

Accepted: 28-Feb-2013 Published: 07-Mar-2013

\section{References}

1. Araujo JF, de Castro AP, Costa MM, Togawa RC, Junior GJ, Quirino BF, Bustamante MM, Williamson L, Handelsman J and Kruger RH: Characterization of soil bacterial assemblies in Brazilian savanna-like vegetation reveals acidobacteria dominance. Microb Ecol 2012, 64:760-70. | Article I PubMed

2. Barns SM, Cain EC, Sommerville L and Kuske CR: Acidobacteria phylum sequences in uranium-contaminated subsurface sediments greatly expand the known diversity within the phylum. Appl Environ Microbiol 2007, 73:3113-6. | Article | PubMed Abstract | PubMed Full Text

3. Barns SM, Takala SL and Kuske CR: Wide distribution and diversity of members of the bacterial kingdom Acidobacterium in the environment. Appl Environ Microbiol 1999, 65:1731-7. | Article I PubMed Abstract | PubMed Full Text

4. Bollmann A, Lewis $K$ and Epstein SS: Incubation of environmental samples in a diffusion chamber increases the diversity of recovered isolates. Appl Environ Microbiol 2007, 73:6386-90. | Article | PubMed Abstract | PubMed Full Text

5. Cannavan FS: A estrutura e composição de comunidades microbianas (Bacteria e Archaea) em fragmentos de carvão pirogênico de Terra Preta de Índio da Amazônia Central. Ph.D. thesis (Graduate Program in Science). Center for Nuclear Energy in Agriculture, University of São Paulo, 2012, 138p. | Website

6. Davis KE, Joseph SJ and Janssen PH: Effects of growth medium, inoculum size, and incubation time on culturability and isolation of soil bacteria. Appl Environ Microbiol 2005, 71:826-34. | Article | PubMed Abstract | PubMed Full Text

7. Davis KE, Sangwan $P$ and Janssen PH: Acidobacteria, Rubrobacteridae and Chloroflexi are abundant among very slow-growing and mini-colony-forming soil bacteria. Environ Microbiol 2011, 13:798-805. I Article I PubMed

8. Dedysh SN, Kulichevskaya IS, Serkebaeva YM, Mityaeva MA, Sorokin VV Suzina NE, Rijpstra WI and Damste JS: Bryocella elongata gen. nov., sp. nov., a member of subdivision 1 of the Acidobacteria isolated from a methanotrophic enrichment culture, and emended description of Edaphobacter aggregans Koch et al. 2008. Int J Syst Evol Microbiol 2012, 62:654-64. | Article I PubMed

9. Dedysh SN, Pankratov TA, Belova SE, Kulichevskaya IS and Liesack W: Phylogenetic analysis and in situ identification of bacteria community composition in an acidic Sphagnum peat bog. Appl Environ Microbiol 2006, 72:2110-7. | Article | PubMed Abstract | PubMed Full Text

10. Eichorst SA, Breznak JA and Schmidt TM: Isolation and characterization of soil bacteria that define Terriglobus gen. nov., in the phylum Acidobacteria. Appl Environ Microbiol 2007, 73:2708-17. | Article I PubMed Abstract I PubMed Full Text

11. Eichorst SA, Kuske CR and Schmidt TM: Influence of plant polymers on 
the distribution and cultivation of bacteria in the phylum Acidobacteria. Appl Environ Microbiol 2011, 77:586-96. | Article | PubMed Abstract | PubMed Full Text

12. Ewing B, Hillier L, Wendl MC and Green P: Base-calling of automated sequencer traces using phred. I. Accuracy assessment. Genome Res 1998, 8:175-85. | Article | PubMed

13. Folman LB, Klein Gunnewiek PJ, Boddy L and de Boer W: Impact of whiterot fungi on numbers and community composition of bacteria colonizing beech wood from forest soil. FEMS Microbiol Ecol 2008, 63:181-91. | Article | PubMed

14. Food and Agriculture Organization (FAO): World Reference Base for Soil Resources. World Soil Resources Report 84, FAO, Rome, 88; 1998.

15. Huey B and Hall J: Hypervariable DNA fingerprinting in Escherichia coli: minisatellite probe from bacteriophage M13. J Bacteriol 1989, 171:252832. | Article | PubMed Abstract | PubMed Full Text

16. Hugenholtz $P$, Goebel BM and Pace NR: Impact of culture-independent studies on the emerging phylogenetic view of bacterial diversity. $J$ Bacteriol 1998, 180:4765-74. | Article | PubMed Abstract | PubMed Full Text

17. Ishikuri $S$ and Hattori T: Formation of bacterial colonies in successive time intervals. Appl Environ Microbiol 1985, 49:870-3. | Article | PubMed Abstract | PubMed Full Text

18. Janssen PH: Identifying the dominant soil bacterial taxa in libraries of 16S rRNA and 16S rRNA genes. Appl Environ Microbiol 2006, 72:1719-28. | Article | PubMed Abstract | PubMed Full Text

19. Janssen $\mathrm{PH}$ : New cultivation strategies for terrestrial microorganisms. In: Zengler K (ed) Accessing Uncultivated Microorganisms: From the Environment to Organisms and Genomes and Back. 2008, 173-192.

20. Janssen PH, Yates PS, Grinton BE, Taylor PM and Sait M: Improved culturability of soil bacteria and isolation in pure culture of novel members of the divisions Acidobacteria, Actinobacteria, Proteobacteria, and Verrucomicrobia. Appl Environ Microbiol 2002, 68:2391-6. | Article | PubMed Abstract | PubMed Full Text

21. Jesus EC, Marsh TL, Tiedje JM, Moreira FMS: Changes in land use alter the structure of bacterial communities in Western Amazon soils. ISME 2009, 3:1004-11. | Article | PubMed

22. Joseph SJ, Hugenholtz P, Sangwan P, Osborne CA and Janssen PH: Laboratory cultivation of widespread and previously uncultured soil bacteria. Appl Environ Microbiol 2003, 69:7210-5. | Article | PubMed Abstract | PubMed Full Text

23. Kim JS, Sparovek G, Longo RM, de Melo WJ, Crowley D: Bacteria diversity of terra preta and pristine forest soil from the western Amazon. Soil Biol Biochem 2007, 39:684-690. | PDF

24. Kishimoto N, Kosako $\mathrm{Y}$, Tano T: Acidobacterium capsulatum gen. nov., sp. nov.: an acidophilic chemoorganotrophic bacterium containing menaquinone from acidic mineral environment. Curr Microbiol 1991, 22:1-7. Article

25. Koch IH, Gich F, Dunfield PF and Overmann J: Edaphobacter modestus gen. nov., sp. nov., and Edaphobacter aggregans sp. nov., acidobacteria isolated from alpine and forest soils. Int J Syst Evol Microbiol 2008, 58:1114-22. | Article | PubMed

26. Kulichevskaya IS, Suzina NE, Liesack W and Dedysh SN: Bryobacter aggregatus gen. nov., sp. nov., a peat-inhabiting, aerobic chemo-organotroph from subdivision 3 of the Acidobacteria. Int J Syst Evol Microbiol 2010, 60:301-6. | Article | PubMed

27. Lane DJ: 16S $\backslash 23 S$ rRNA sequencing. In: Stackebrandt $E$ and Goodfellow M (ed) Nucleic Acid Techniques in Bacterial Systematics 1991, 115-147.

28. Larkin MA, Blackshields G, Brown NP, Chenna R, McGettigan PA, McWilliam H, Valentin F, Wallace IM, Wilm A, Lopez R, Thompson JD, Gibson TJ and Higgins DG: Clustal $W$ and Clustal $X$ version 2.0. Bioinformatics 2007, 23:2947-8. | Article | PubMed

29. Mochizuki M, Hattori T: Kinetics of microcolony formation of a soil oligotrophic bacterium, Agromonas sp. FEMS Microbiol Ecol 1986, 38:51-55. | Article

30. Navarrete AA, Cannavan FS, Taketani RG, Tsai SM: A molecular survey of the diversity of microbial communities in different Amazonian agricultural model systems. Diversity 2010, 2:787-809. | Article

31. Navarrete AA, Kuramae EE, de Hollander M, Pijl AS, van Veen JA and Tsai SM: Acidobacterial community responses to agricultural management of soybean in Amazon forest soils. FEMS Microbiol Ecol 2013, 83:607-21. I Article | PubMed

32. Pankratov TA: Acidobacteria in microbial communities of the bog and tundra lichens. Microbiology 2012, 81:51-58. | Article

33. Pankratov TA and Dedysh SN: Granulicella paludicola gen. nov., sp. nov.,
Granulicella pectinivorans sp. nov., Granulicella aggregans sp. nov. and Granulicella rosea sp. nov., acidophilic, polymer-degrading acidobacteria from Sphagnum peat bogs. Int J Syst Evol Microbiol 2010, 60:2951-9. | Article | PubMed

34. Pankratov TA, Serkebaeva YM, Kulichevskaya IS, Liesack W and Dedysh $\mathrm{SN}$ : Substrate-induced growth and isolation of Acidobacteria from acidic Sphagnum peat. ISME J 2008, 2:551-60. | Article | PubMed

35. Ruivo MLP, Amarante CB, Oliveira MLS, Muniz ICM, Santos DAM: Microbial population and biodiversity in Amazonian Dark Earth soils. In: Woods WI (ed) Amazonian Dark Earths: Wim Sombroek's Vision 2009, 351-362.

36. Russell EJ: Soil conditions and plant growth. Longmans, London: Green and Co.; 1950

37. Sait M, Hugenholtz $\mathrm{P}$ and Janssen PH: Cultivation of globally distributed soil bacteria from phylogenetic lineages previously only detected in cultivation-independent surveys. Environ Microbiol 2002, 4:654-66. | Article PubMed

38. Sait M, Davis KE and Janssen PH: Effect of pH on isolation and distribution of members of subdivision 1 of the phylum Acidobacteria occurring in soil. Appl Environ Microbiol 2006, 72:1852-7. | Article | PubMed Abstract I PubMed Full Text

39. Schloss PD, Westcott SL, Ryabin T, Hall JR, Hartmann M, Hollister EB, Lesniewski RA, Oakley BB, Parks DH, Robinson CJ, Sahl JW, Stres B, Thallinger GG, Van Horn DJ and Weber CF: Introducing mothur: open-source, platform-independent, community-supported software for describing and comparing microbial communities. Appl Environ Microbiol 2009, 75:7537-41. | Article | PubMed Abstract | PubMed Full Text

40. Secretaria de Estado de Planejamento e Coordenação Geral (SEPLAN) (2001). Mapa de solos do Estado de Mato Grosso, Mato Grosso. Available at: www.seplan.mt.gov.br (last accessed in 25 Jul. 2011).

41. Stevenson BS, Eichorst SA, Wertz JT, Schmidt TM and Breznak JA: New strategies for cultivation and detection of previously uncultured microbes. Appl Environ Microbiol 2004, 70:4748-55. | Article | PubMed Abstract | PubMed Full Text

42. Stott MB, Crowe MA, Mountain BW, Smirnova AV, Hou S, Alam M and Dunfield PF: Isolation of novel bacteria, including a candidate division, from geothermal soils in New Zealand. Environ Microbiol 2008, 10:2030-41. | Article | PubMed

43. Tamura K, Dudley J, Nei M and Kumar S: MEGA4: Molecular Evolutionary Genetics Analysis (MEGA) software version 4.0. Mol Biol Evol 2007, 24:1596-9. | Article | PubMed

44. Tschech $A$ and Pfennig N: Growth yield increase linked to caffeate reduction in Acetobacterium woodii. Arch Microbiol 1984, 137:163-167. Article

45. Valášková V, de Boer W, Gunnewiek PJ, Pospisek M and Baldrian P: Phylogenetic composition and properties of bacteria coexisting with the fungus Hypholoma fasciculare in decaying wood. ISME J 2009, 3:1218-21. | Article | PubMed

46. Vartoukian SR, Palmer RM and Wade WG: Strategies for culture of 'unculturable' bacteria. FEMS Microbiol Lett 2010, 309:1-7. | Article | PubMed

47. Zimmermann J, Gonzalez JM, Saiz-Jimenez C, Ludwig W: Detection and phylogenetic relationships of highly diverse uncultured acidobacterial communities in altamira cave using 235 rRNA sequence analyses. Geomicrobiol J 2005, 22:379-388. | PDF

48. Weisburg WG, Barns SM, Pelletier DA and Lane DJ: 16S ribosomal DNA amplification for phylogenetic study. J Bacteriol 1991, 173:697-703. | Article | PubMed Abstract | PubMed Full Text

49. Widdel F, Kohring G-W, Mayer F: Studies on dissimilatory sulfate-reducing bacteria that decompose fatty acids III. Characterization of the filamentous gliding Desulfonema limicola gen. nov. sp. nov., and Desulfonema magnum sp. nov. Arch Microbiol 1983, 134:286-294. | Article

50. Winding A, Binnerup SJ and Sorensen J: Viability of indigenous soil bacteria assayed by respiratory activity and growth. Appl Environ Microbiol 1994, 60:2869-75. | Article | PubMed Abstract | PubMed Full Text

\section{Citation:}

Navarrete A A, Barreto C C, Arnaldo M and Tsai S M: Molecular detection on culture medium of Acidobacteria from Amazon soils. Microbiology Discovery 2013, 1:1. http://dx.doi.org/10.7243/2052-6180-1-1 